\title{
Influence of Socio-economic Characteristics of Farmers on their Use of Social Media in Haryana, India
}

\author{
N.P. Darshan ${ }^{1 *}$, B.S. Meena ${ }^{2}$ and H.R. Meena ${ }^{2}$ \\ ${ }^{1}$ Agricultural Extension Division, PJTSAU, Hyderabad-500030, Telangana, India \\ ${ }^{2}$ Dairy Extension Division, National Dairy Research Institute, Karnal-132001, Haryana, India \\ *Corresponding author
}

\section{A B S T R A C T}

\begin{tabular}{|l|}
\hline K e y w o r d s \\
Farmers, \\
Agricultural \\
information, \\
Social media, \\
Socio-economic, \\
Smart-phones. \\
\hline Article Info \\
\hline $\begin{array}{l}\text { Accepted: } \\
\text { 04 September } 2017 \\
\text { Available Online: } \\
\text { 10 October } 2017\end{array}$ \\
\hline
\end{tabular}

In order to explore the use of social media by farmers and adapt them for exchanging agricultural information it is necessary to understand their socio-economic status. In this view, a study was conducted to analyze socio-economic characteristics of farmers and their influence on social media use in Karnal district of Haryana state. A total of 40 respondents were selected randomly constituted sample size and data collection was done through semi-structured interview schedule. Results of the study revealed that majority of farmers ( $80 \%$ ) belonged to young age group (upto 35 years) who were mostly attracted by social media. Majority farmers (40\%) completed up to matriculation level of education for which using social media was easy. Around 62.50 per cent farmers' families belonged to medium education status (2.00-3.20) which encourage usage of modern information sources. 45.00 per cent respondents followed crop plus dairy combination as their primary occupation and 60.00 per cent has annual income of INR. 114946- 460353 which provided affordability for using modern media tools like smart-phones $(77.50 \%)$, laptops $(15 \%)$. The study recommends the need for considering socio-economic conditions of farmers as it influences the affordability and use of social media.

\section{Introduction}

Information is critical in agricultural development because it is a tool for communication between stakeholders and serves as a channel for assessing trends and shaping decisions (Kalusopa, 2005). Farming requires information and technical expertise hence the need for extension services however, due to various factors extension services are not readily available to all farmers. A consensus exists that extension services, if functioning effectively, improve agricultural productivity by providing farmers with information that helps them to optimize their use of limited resources (Muyanga and
Jayne, 2006). Globalization and technological change processes that have accelerated in tandem over the past years have created a new global economy powered by technology, fueled by information and driven by knowledge.

Agriculture sector is also witnessing radical changes and challenges at national and global level. The slow growth observed in the agriculture sector is causing concerns for the future food and nutritional security of the country. The number of clients who need to be covered by extension services is large, and 
the cost of reaching them is high. Adding to this challenge, farmers' information needs vary even within a given geographical area because of variations in soil, elevation, microclimate, and farmers' means enterprises and capabilities.

The emerging challenges and opportunities call for a paradigm shift in the innovation driven agricultural research system to connect inventions with all the stakeholders in the entire food supply chain. Social media and internet are embracing almost all the sectors of life. In agriculture there is a need to reach each and every farmer and provide them the updated information.

Communities of social media are open networks where everyone (i.e. clients, users, members) has an opportunity to contribute their ideas and to support mass innovation with one-to-one, one-to-many, and many-tomany interactions (Ashley et al., 2009). The use of social media by farmers is affected by their socio-economic status. So keeping these points in mind the study was mainly focused to reveal the socio-economic variables associated with the farmers of karnal district.

\section{Materials and Methods}

\section{Description of study area}

The study was conducted in Karnal district of Haryana. Karnal, 'the city of Daanvir Karan' was formed as a District on November1, 1966. It is $123 \mathrm{~km}$ from Delhi on the National Highway NH1, (called the GT Road), and 126 $\mathrm{km}$ from Chandigarh. It lies between 29 09'50" and 29 50' North latitude and 76 31' $15^{\prime \prime}$ and $7712^{\prime} 45^{\prime \prime}$ East longitude, its height from sea level is around 240 meters. The district was purposively selected as it has contributed extensively to the green revolution and the socio economic status and literacy level of the respondents was good.

\section{Sampling technique}

Since the distribution of the social media users in the district is unknown whosoever come in contact with ICAR and other agricultural institutes/departments were selected (most of the contacts were gathered from the institutes). The list of names was gathered from KVKs, ICAR institutes located in Karnal and sampled randomly. A total of 40 farmer households constituted the sample size. A structured, pre-tested interview schedule was developed for collecting data from the respondents according to the objective of the study. Data were collected from the respondents by conducting personal interview method.

\section{Results and Discussion}

The results of the investigation carried out are presented through the table 1 showing the socio-economic characteristics of farmers who have opted social media as source of information and use them for exchange of information. It could be observed from table 1 that majority $(80.00 \%)$ of the farmers' belonged to young age group (up to 35 years). This was probably due to the fact that majority of the farmers were literate and the emergence of Smart phones, Facebook and Whatsapp had been giving virtual communication experience. Hence, majority of young farmers were attracted towards using social media (Darshan, 2015).

Results pertaining to the education indicated that, 40.00 per cent, 37.50 per cent and 22.50 per cent of social media user-farmers had education level up to matriculate, intermediate and graduation and above respectively. This level of literacy could be due to good financial conditions, provision of better educational facilities in the study areas and farmers were aware of importance and need of education. This had influenced easy 
usage of social media tools. Most of the farmers were aware of using Facebook (90\%) and Whatsapp (77.50\%). With respect to land holding, 35.00 per cent farmers had marginal land holdings (up to 1 ha.) and 35.00 per cent were having small land holding (1-2 ha.) followed by medium (12.00\%) and then semimedium and large $(10.00 \%)$ and $(8.00 \%)$ respectively. Even though majority of farmers belonged to small and marginal category of land holdings they were not denied of using social media as the lands were irrigated and got sufficient income for affording modern media tools like smart-phones $(77.50 \%)$ and laptops (15\%) (Tables 2 and 3).
The results shows that 45.00 per cent of the farmers were practicing crop+ dairy combination of occupation, followed by crop + dairy farming + business $(23.00 \%)$ and then Service + crop + dairy farming $(20.00 \%)$ and crop only $(12.00 \%)$

Farm mechanization had allowed some of the young farmers (about $40.00 \%$ ) to involve in services and other business activities also. Farmers were more cosmopolite and exposed to various sources of information since green revolution and access to social media tools to get information about agricultural and allied activities.

Table.1 Profile characteristics of social media user-farmers

\begin{tabular}{|c|c|c|c|c|}
\hline & & & & $(n=4$ \\
\hline S. No. & Variables & Category & Frequency & Percentage \\
\hline \multirow{3}{*}{1} & \multirow{3}{*}{ Age (in year) } & Young (Up to 35$)$ & 32 & 80.00 \\
\hline & & Middle (36-50) & 8 & 20.00 \\
\hline & & Old (Above 50) & 0 & 0.00 \\
\hline \multirow{3}{*}{2} & \multirow{3}{*}{ Education } & Matriculation & 16 & 40.00 \\
\hline & & Intermediate & 15 & 37.50 \\
\hline & & Graduate and above & 9 & 22.50 \\
\hline \multirow{3}{*}{3} & \multirow{3}{*}{$\begin{array}{l}\text { Family Education } \\
\text { Status }\end{array}$} & Low (up to 2.00) & 7 & 17.50 \\
\hline & & Medium (2.0-3.2) & 25 & 62.50 \\
\hline & & High (more than 3.2) & 8 & 20.00 \\
\hline \multirow{5}{*}{4} & \multirow{5}{*}{ Land holding } & Marginal & 14 & 35.00 \\
\hline & & Small & 14 & 35.00 \\
\hline & & Semi medium & 4 & 10.00 \\
\hline & & Medium & 5 & 12.50 \\
\hline & & Large & 3 & 7.50 \\
\hline \multirow{4}{*}{5} & \multirow{4}{*}{$\begin{array}{l}\text { Occupation (Main + } \\
\text { secondary) }\end{array}$} & Crop alone & 5 & 12.50 \\
\hline & & Crop + dairy & 16 & 45.00 \\
\hline & & $\begin{array}{c}\text { Service+ crop+ dairy } \\
\text { farming }\end{array}$ & 8 & 20.00 \\
\hline & & $\begin{array}{c}\text { Crop+ dairy farming }+ \\
\text { business }\end{array}$ & 9 & 22.50 \\
\hline \multirow{3}{*}{6} & \multirow{3}{*}{ Annual income } & Up to INR 114946 & 9 & 22.50 \\
\hline & & INR 114946-460353 & 24 & 60.00 \\
\hline & & More than INR 460353 & 7 & 17.50 \\
\hline
\end{tabular}


Table.2 Distribution of farmers using various social media tools

\begin{tabular}{|l|c|c|}
\hline Category & Farmers & Percentage \\
\hline Facebook & 36 & 90.00 \\
\hline Whatsapp & 31 & 77.50 \\
\hline Google+ & 26 & 65.00 \\
\hline Twitter & 6 & 15.00 \\
\hline
\end{tabular}

Table.3 Distribution of farmers based on the possession of ICT tools

\begin{tabular}{|c|c|c|}
\hline Category & Farmers & Percentage \\
\hline TV & $40(100.00)$ & 100 \\
\hline Radio & $19(47.50)$ & 47.50 \\
\hline Computer(desktops) & $2(5.00)$ & 5.00 \\
\hline Mobile & $36(90.00)$ & 90.00 \\
\hline Smart phones & $31(77.50)$ & 77.50 \\
\hline Laptop & $6(15.00)$ & 15.00 \\
\hline Tablet & $5(12.50)$ & 12.50 \\
\hline
\end{tabular}

$(n=40)$

The study reveals that majority of the farmers $(60.00 \%)$ falls under the medium income of INR.114946-460353 followed by 22.50 per cent and 17.50 per cent belonged to low (up to INR. 114946) and high (more than INR. 460353) category of income respectively. This allowed the farmers to afford gadgets suitable for access social media tools.

A critical analysis of socio-economic characteristics of farmers who use social media revealed that majority of farmers belong to young and middle age group and majority of young farmers happened to be small and marginal farmers. Since most of the farmers are young, we can reinforce their entrepreneurial behavior by providing attractive and relevant information through social media. Majority of farmer households had medium family education status it is possible to use social media as one of the media mix and as a supplement and compliment to conventional transfer of technology programs. It can reduce the burden on insufficient extension personnel. As a part of digital India campaign, to impart digital education to all social media can be the excellent tool to small and marginal farmers. It is also revealed that majority of farmers depend on combination of cropping systems for their income rather than single cropping patterns. To flourish this user friendly, sustainable, scientific, location specific technology generation is necessary to meet the needs. It is an important obligation on the part of extension system (both public and private) to continue giving support mechanisms to social media user-farmers.

\section{Acknowledgments}

I would like to thank my chairperson Dr. B. S. Meena for guiding me throughout my research study. I thank Dairy Extension Division of National Dairy Research Institute Karnal for allowing me to pursue my research study. I thank all the farmers who gave suitable information for the research study.

\section{References}

Ashley, H., Corbett, J., Jones, D., Garside, B. and Rambaldi, G. 2009. Change at Hand: Web 2.0 for Development. 
Participatory Learning and Action, 59: 8-20.

Darshan, N.P., 2015. Exploring the potential use of social media in communicating agricultural information in Haryana. M.Sc. Thesis. National Dairy Research Institute. Karnal (India).

Kalusopa, T., 2005. The Challenges of Utilising Information and Communication Technologies (ICT's) for the small scale farmer in Zambian.
IN: Library Tech, 23(3)414-424, www.emeraldinsight.com/0737-

8831.htm. Retrieved on 8th January, 2011.

Muyanga, M., and Jayne, T.S. 2006. Agricultural Extension in Kenya: Practice Policy and Lessons. Practice and Policy Lessons. Tegemeo Institute of Agriculture and Policy Development, Egerton University.

\section{How to cite this article:}

Darshan, N.P., B.S. Meena and Meena, H.R. 2017. Influence of Socio-economic Characteristics of Farmers on their Use of Social Media in Haryana, India. Int.J.Curr.Microbiol.App.Sci. 6(10): 14-18. doi: https://doi.org/10.20546/ijcmas.2017.610.002 